\title{
BUILDING INFORMATION MODELING V ROZPOČTOVÁNÍ BUILDING INFORMATION MODELING IN BUDGETING
}

\author{
Ing. Michal Strnad \\ Faculty of Civil Engineering, CTU in Prague, Thakurova 7, 16629 Prague 6, Czech Republic, \\ michal.strnad@fsv.cvut.cz
}

\begin{abstract}
Abstrakt - CZ
Stavební činnost patří k finančně náročným a stále se měnícím místům realizace. Základní myšlenkou rozpočtu je sestavení všech možných nákladů, které vzniknou při stavební činnosti. Rozpočet musí tvořit transparentní a efektivní způsob komunikace v souvislosti dodavatelsko-odběratelských vztahů. Z tohoto důvodu je podstatné, aby byla dána struktura, která je dnes reprezentována cenovou soustavou. Je důležité dodržovat principy rozpočtování a technické normy. Je třeba mít k dispozici kvalitní podklady $k$ tvorbě rozpočtů jako je projektová dokumentace a mnohé další. Stavební sortiment je však jeden z nejrozsáhlejších, při kterém se může skupina produktů v rámci investiční fáze několikrát změnit nejen materiálně, ale též cenově, nebot' stavebnictví disponuje nejdelším výrobním cyklem.
\end{abstract}

\section{Klíčová slova - CZ}

Informační modelování budov, životní cyklus stavby, software pro rozpočtování

\section{Abstract - EN}

Construction activity is one of the financially demanding and ever-changing locations of implementation. The basic idea of the budget is to determine all the possible costs that will arise during construction work. The budget must be a transparent and effective way of communication in the context of supplier-customer relationships. For this reason it is essential to give the budget the structure that is now represented by the price system. It is important to adhere to the principles of budgeting and technical standards. It is necessary to have good documentation for budgeting such as project documentation and much more. However, the construction product range is one of the most extensive, the product group can be changed several times in the investment phase not only materially but also cost-effectively because of the longest production cycle in the construction industry.

\section{Keywords - EN}

Building information modelling, the life cycle of buildings, costing software

\section{JEL Classification}

C51 Model Construction and Estimation

C53 forecasting and prediction methods; simulation methods

DOI: https://doi.org/10.14311/bit.2017.02.02

Editorial information: journal Business \& IT, ISSN 2570-7434, CreativeCommons license (c) (i) published by CTU in Prague, 2017, http://bit.fsv.cvut.cz/ 


\section{BIM v kalkulacích a rozpočtování}

Model BIM přináší rozsáhlé množství dílčích přínosů, a to od pokročilých metod vizualizace přes zjednodušení rízení výstavby až po sní̌ení nákladů na provoz budovy. Pro výstavbové projekty je typická úroveň rizika zvláště $v$ prvních etapách projektu. Úroveň rizika je především z hlediska postupně vynakládaných finančních prostředků, které mohou způsobit selhání v řizení projektu výstavby.

Pro co nejreálnější rozpočet jsou důležitá vstupní data, na které Ize nahlížet jako rizika ovlivňující náklady v investiční a provozní fázi. Proto Ize vliv na celý životní cyklus projektu pomysIně rozčlenit na rizika způsobená lidským, technickým případně politickým faktorem. Působení jednotlivých faktorů není v životním cyklu projektu od začátku do ukončení projektu, ale vstupuje do cyklu dle jednotlivých činností a fází projektu [14, 15].

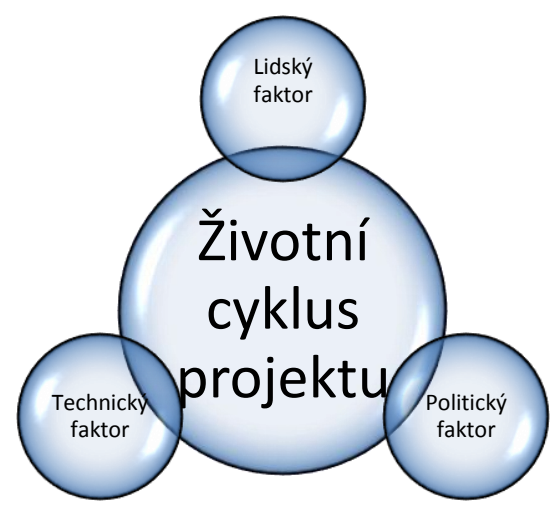

Obr 1: Schéma působení jednotlivých faktorů na životní cyklus stavby (zdroj: vlatní)

\section{Použití BIM v rozpočtování}

Mluví-li se o rozpočtování a rozpočtech staveb, v zásadě se vždy jedná o strukturovaný výčet nákladů, které vznikají z určité konkrétní lidské činnosti. Se stavebními rozpočty tak dříve či později přijde do kontaktu každý, kdo se účastní stavebního řízení $[5,13]$. Přestože každý účastník hledí na rozpočet a rozpočtování ze svého úhlu pohledu, všichni mají stejný cíl - zjistit, kolik daná stavba nebo stavební činnost bude stát peněz. Proto je pro rozpočtování stěžejní výstup z BIM softwarových aplikací pro navrhování, mezi které se např́klad řadí [4, 17]:

- Bentley Architecture

- Nemetschek Allplan Architecture

- Graphisoft ArchiCAD

- Autodesk Revit Architecture

Při navrhování se musí dbát na kolize stavebních konstrukcí, které by zapřičinily neadekvátní rozpočet, nebot' by se z důvodu daných kolizí rozpočtovaly práce opakovaně $[3,6]$.

V České republice se pro tvorbu rozpočtů používají zejména níže uvedené softwary:

- BUILDpower

- KROS plus

- euroCALC 
Položky výkazu výměr ze softwarových aplikací pro navrhování musí být pro korektní zpracování shodné s položkami případně agregovanými položkami z rozpočtářských programů. Dále je nezbytné, aby $v$ programech pro rozpočtování byly obvyklé ceny, a nikoliv pouze ceny vznikající průběžnou indexací [10]. Struktura jednotkových (resp. agregovaných) cen musí umožňovat jejich aktualizaci v co nejkratším časovém intervalu. Tím se dosáhne provázání cen $v$ softwaru a reálných tržních cen. $\mathrm{Na}$ tomto základě bude možné dobře reagovat na vývoj cen, úspor a prodražení zakázky. Aktualizací cen softwaru pro oceňování $v$ návaznosti na BIM dojde ke značným finančním a časovým úsporám při př́pravě a realizaci stavby, ale též ve fázi provozní $[2,8,9]$.

\section{Rizika ve spojení s BIM v kalkulacích a rozpočtování}

\section{Rizika způsobená lidským faktorem}

a) Projektová dokumentace

- kvalita materiálů s návazností na nižší provozní náklady (opravy, výměna,...)

$\checkmark$ realizační prípravě se rozhoduje o vlastnosti stavby z hlediska jejich bezpečnosti, odolnosti, prostorového uspořádání a technické vybavenosti. Je-li stavba $v$ souladu s normovými parametry, projektová dokumentace upřesňuje požadavky na materiály, technologické postupy a na kvalitu a zpưsob provádění stavebních prací. Normové parametry jsou klíčové z hlediska návrhu a realizace stavby, ale bohužel se investor (developer) neohliží na další aspekty jako je výše provozních nákladů, která je úzce spjatá se životností a kvalitou navržených materiálů. Přínosem BIM je propojení projektové dokumentace až po Facility management, což má nepostradatelný význam jak pro budoucí vlastníky nemovitosti, tak nájemníky, kterým se projeví kvalitativní zpracování projektu v provozních nákladech (měsíční zálohy,...)

b) Výkaz výměr

- souběh stavebních konstrukcí v jednom úseku (při projektování byla jedna konstrukce překryta druhou)

Pro stanovení výkazu výměr je nesmírně důležité, aby nebyla překryta jedna konstrukce druhou. To znamená, aby nedošlo $\mathrm{k}$ vložení dvou stropních desek v jedné výškové úrovni př́padně vložení více stěn $v$ témže místě.

- nepřesný součet výměr

Při samotném sčítání jednotlivých položek musí být zajištěna přesnost výpočtu, kterou bude Building Information Modeling ve spojitosti lidského faktoru rozhodně docílena.

\section{Rizika způsobená technických faktorem}

a) projektová dokumentace

Building Information Modeling ve fázi projektování umožní analýzu slunečních a světelných modelů, která simuluje například dopad slunečního světla na budovu a umožní analyzovat s tím související stíny okolních konstrukcí nebo pomůže nalézt optimální architektonické uspořádání. S tím souvisí i možnost vytvoření modelu denního cyklu a s tím souvisejícího osvícení v závislosti na lokalitě projektu. Takovéto analýzy můžou vést nejen $\mathrm{k}$ lepšímu technickému a technologickému řešení projektu, ale také např́klad k následným analýzám $v$ průběhu provozní fáze projektu a s tím souvisejících úspor v energiích.

Podstatným tématem udržitelnosti je i problematika údržby a rekonstrukcí. $V$ tomto ohledu lze použít nástroje $\mathrm{k}$ podrobnější analýze konkrétních detailů projektu tak, aby došlo k optimálnímu využití prostoru, nedocházelo ke zbytečnému plýtvání například vodními i jinými zdroji a hlavně aby př́padné 
rekonstrukce a dodatečná údržba byly co nejméně problémové. Jedná se tak zejména o využívání snadno opravitelných a udržovatelných prvků a o takový návrh budovy, jaký bude brát $v$ úvahu udržitelnost projektu v jeho provozní fázi [12].

b) výkaz výměr

- kalkulace neidentifikovatelných položek (vzduch, ...)

Building Information Modeling umožňuje pracovat chytřejším způsobem a tím i zefektivnit produkci a vylepšit výstupy. BIM je nástroj, který je třeba kontrolovat ladit, ale je však třeba řešit velké množství individuálních problémů. Příkladem může být automatizace tvorby výkazu výměr. Vytvoření seznamu prvků modelu je otázkou malé chvilky. Seznam je pak ale stejně třeba doplnit o v modelu chybějící části konstrukcí, zkontrolovat, nebo odstranit vzniklé chyby. Jednou z chyb, která aktuálně vzniká při tvorbě výkazu výměr, je započítávání ploch a objemů vzduchu.

c) stavební rozpočet

- aktualizace cen v softwaru pro rozpočtování

Tak jako nejsou dokonalé lidské zdroje, tak nejsou dokonalé zdroje technické respektive data. Množství stavebních prvků a materiálů je značně rozsáhlé, proto jsou velice důležité aktualizace a doplnění položek do BIM v co nejkratším časovém intervalu a s tím souvisejících cen, které se dále odrážejí při celkové ceně projektu.

\section{Rizika způsobená politickým faktorem}

Politický faktor se promítne v kalkulacích a rozpočtování i bez působení BIM. Jednotlivé faktory (např. míra inflace, stavební zákon, zákon o veřejných zakázkách, zákon o cenách,...) nelze proto považovat pouze za rizika způsobená zavedením BIM.

\section{Rizika vyplývající z implementace BIM}

Implementace Building Information Modelingu má ekonomický a i vliv personální. V prvé řadě se jedná o nákup softwaru společnostmi, které zajištují ćinnosti související s výstavbou, ale i se samotným provozem. Je možné, že některé společnosti budou muset zakoupit i nové počítače, které dokážou pracovat s náročnými softwary, což se promítne do zvýšení pořizovacích nákladů společnosti. Zvýšení nákladů a snižení produktivity práce bude ve fázi implementace závislé na schopnosti, kvalitě, pochopení a znalosti zaměstnanců, kteří se budou se softwary učit a v budoucnu jej používat. Pro úspěšné používání BIM je nutné, aby přistupovali k implementaci BIM optimisticky i subdodavatelé, kteři tvoří značný podíl činností v investiční fázi.

Př́nosem pro společnost může být fakt, že se díky zavedení BIM, spolupráci s akademickým prostředím a zpětnou vazbou stanou vedoucí firmou na trhu. Zpětná vazba neboli shromažd'ování informací a jejich vyhodnocení posílí činnost společnosti a tím se zvýší i produktivita zaměstnanců.

Zvýšení nákladů a snížení produktivity práce při zavádění BIM se vedoucí firmě na trhu prípadně tržnímu vyzyvateli může vrátit zavedením vzdělávacích kurzů zaměstnanci nejen pro svou společnost, ale též pro ostatní společnosti nejen na národní působnosti. Lídr trhu nesmí však opomenout, že konkurence ve stavebnictví a inovacích je vysoká, proto musí vedle posilování věrnosti zákazníků zajištovat stále přidanou hodnotu, aby se nepropadl na druhou pozici na trhu a nestal se pouze tržním vyzyvatelem. 
V druhé řadě ovlivní implementace BIM investory, a to promítnutím úměrné části pořizovacích nákladů implementace BIM vzhledem $\mathrm{k}$ rozsahu projektu do investičních nákladů projektu/stavby. Investor si však musí uvědomit navýšení investičních nákladů, které ocení v dlouhodobějším časovém horizontu snižením provozních nákladů.

V neposlední řadě má vliv implementace BIM na uživatele objektu, kterým se snižení provozních nákladů objektu promítne do výše fakultativních poplatků.

Výčet rizik je pro lepší přehlednost uveden v následující tabulce [1]:

\begin{tabular}{|c|c|}
\hline Účastník projektu & Riziko \\
\hline \multirow{5}{*}{ Dodavatel } & Neochota komunikace s ostatními účastníky \\
\hline & Návratnost investičních finančních prostředků do implementace BIM \\
\hline & Vzdělávání vlastních zaměstnanců \\
\hline & Technická znalost problematiky \\
\hline & Laxní přístup subdodavatelů k BIM \\
\hline Investor & $\begin{array}{l}\text { Neocenění prrínosu využití BIM (investor se neohliží na porovnání růstu } \\
\text { investice a snížení nákladů ostatních etap) }\end{array}$ \\
\hline \multirow{2}{*}{$\begin{array}{l}\text { Uživatel/ Facility } \\
\text { manager }\end{array}$} & Technická znalost problematiky \\
\hline & Znalost softwaru pracujícího s modelem BIM \\
\hline
\end{tabular}

Tab. 1: Přehled rizik jednotlivých účastníků projektu ve fázi implementace BIM (zdroj: vlastni)

\section{Výhody vyplývající z používání BIM}

$V$ dnešní době již téměř všichni architekti BIM používají a mnozí o tom ani neví. Základem BIM je totiž 3D geometrický model, který vzniká snad při každém návrhu stavby. Používáním BIM by mohli projektanti vyřešit kolize, které zpravidla vznikají při realizaci výstavby. Používáním mohou definovat vlastnosti materiálu, popis výrobce, cenu a mnohé další, které usnadní navazující zpracování jednotlivých stupňů dokumentace. Rozpočtář nemusí vypracovávat výkaz výměr, pouze zkontroluje a odstraní či doplní nedostatky, které dnes při výkazu výměr v BIM softwaru vznikají [11].

Z hlediska investora patří mezi hlavní výhody používání BIM možnost průběžné kontroly stavu návrhu projektu. Protože jsou data o stavbě $v$ predem definovaném formátu a struktuře, je možné postupně vypracovávat např́klad posudky a kontrolní analýzy. Jelikož jsou vstupní data zpřesňována, není nutné vždy znovu vytvářet analytický model. Přínosem pro investora je snižení organizačních nákladů, kdy nemusí vynakládat vysoké finanční prostředky na provoz a údržbu majetku.

Investor jakožto Státní správa nakládá s rozsáhlým inventářem budov. Mezi budovy se většinou zařazuje městský úřad, úřady jednotlivých odborů, domy s pečovatelskou službou, ústavy pro zdravotně postižené, domovy pro seniory, mateřské školy, základní a střední školy. $V$ tomto rozsáhlém inventáři je klíčové mít informace o jednotlivých objektech centralizované. 
Používáním Building Information Modelingu ve státní správě si může kdokoliv vyžádat informace o dané budově $v$ inventáři státní správy, a zároveň nahlédnout, zda už podobná informace nebyla zpracována. Tím by nedocházelo ke zpracování dost podobných činností (např. energetický audit, PENB, ekologický audit, interní audit, ...) jednotlivými odbory úřadů, což má za důsledek nesprávné hospodaření s finančními prostředky $[11,16]$.

Z uvedeného př́kladu vyplývá, že BIM s návazností na rozpočtářské programy má své významné opodstatnění i ve státní správě. A jelikož má státní zadavatel největší postavení na trhu, tak stojí za uvážení, jestli by zrovna stát neměl být tím, kdo by měl vyžadovat v rámci zvyšujících se standardů projekty už jen v BIM.

Činnosti Facility managementu se vyznačují správou budov, využitelností budov, správou energií úklidem, údržbou atd. Pro Facility management je důležité mít velmi dobře zpracované strategické a taktické plány pro zajištění komplexnosti podpůrných činností FM. Používání BIM v provozní fázi by přinesl odstranění nedostatků, s kterými se setkávají Facility manažeři, již v př́pravné fázi při projektové dokumentaci [7]. To by mělo za následek:

- snižení spotřeby energií

- úspory ve správě majetku

- efektivnější využívání prostor

- plánování výměny nábytku a zařízení

Výhody při používání BIM jsou pro lepší přehlednost uvedeny v následující tabulce [1]:

\begin{tabular}{|c|c|}
\hline Účastník projektu & Výhody \\
\hline \multirow{3}{*}{ Dodavatel } & Propojení profesí s architektonickým návrhem \\
\hline & Propojení profesí s projekty stavební části \\
\hline & Energetické simulace \\
\hline \multirow{5}{*}{ Investor } & Kontrola projektu ve všech jeho fázích \\
\hline & Proces změn a požadavků na objekt (vícepráce,...) \\
\hline & Nízké provozní náklady \\
\hline & $\begin{array}{l}\text { Opravy a údržba stavebních prvků v krátkém časovém } \\
\text { horizontu }\end{array}$ \\
\hline & Návaznost četnosti oprav a údržby na další investice \\
\hline \multirow{4}{*}{$\begin{array}{l}\text { Uživatel/ } \\
\text { manager }\end{array}$} & Nízké provozní náklady \\
\hline & Četnost oprav a údržby v důsledku investiční fáze \\
\hline & Informace o údržbě stavebních částí \\
\hline & Jednoduché výkazy stavebních částí, ploch, objemů \\
\hline
\end{tabular}

Tab. 2: Přehled výhod pro jednotlivé účastníky projektu při použivání BIM (zdroj: vlastní) 


\section{Závěr}

Building Information Modeling není náhražkou lidských zdrojů, naopak k dosažení optimální fáze plánování, projektování, realizace a provozu je spojitost lidského a technického faktoru velmi důležitá. Propojením rozpočtářských programů a BIM se zefektivní tvorba stavebních rozpočtů, kalkulací, stanovení lhůty výstavby, dojde k provázání informací o dodavatelích jednotlivých částí a zpưsob jejich kontroly. Aktuálnost informací a zpětná vazba programů docílí zájmu v soukromé, ale i ve veřejné sfére. Dnes také není možné určit ekonomický přínos zavedení systému BIM, který přináší vyšší nároky na zpracování projektu, ale sniží finanční nároky na vícepráce, které stavbu značně prodražují. Odborné články sice poukazují na náklady životního cyklu stavby a zabývají se implementací BIM, ale žádný z nich se nezaměřuje aktualizací cen $v$ rozpočtářských programech s následným propojením s BIM [14].

\section{Poděkování}

Tato práce byla podpořena interním studentským grantem Českého vysokého učení technického v Praze, č. SGS17/023/OHK1/1T/11.

\section{Literatura}

[1] Martin Černý a kolektiv autorů. BIM př́ručka. Praha: Odborná rada pro BIM, 2013. ISBN 978-80-2605279-5

[2] Nessim Hanna; H. Robert Dodge. Pricing, Zásady a postupy tvorby cen. Vydání. 1. Praha: Management Press, 1997.

[3] Pour Pavel, Ptáček Roman. BIM projektování v ArchiCADu. Riba Publishing, Vydání. 2. Praha: Grada Publishing, 2012. ISBN 78-80-247-4165-9

[4] Eric Wing. Autodesk Revit architecture 2011 : no experience required. Riba Publishing, Wiley Publishing, 2010. ISBN 978-0-470-61011-4.

[5] Matějka, P., Hromada, E., Anisimova, N., Dobiáš, J., Kovář, P., \& Kozáková, I. (2012). Základy implementace BIM na českém stavebním trhu (1. ed.). Praha: Fineco.

[6] Hrazdil. Modelování a řízení výstavbového procesu pomocí programů CONTEC a BUILD-POWER. Praha: ČVUT Praha, Fakulta stavební, 2000.

[7] SCHNEIDEROVÁ HERALOVÁ, R. Life Cycle Costing Within Infrastructure Projects. In: HÁJEK, P., et al., eds. Central Europe towards Sustainable Building 2016 - Innovations for Sustainable Future. Central Europe towards Sustainable Building 2016 Innovations for Sustainable Future. Prague, 22.06.2016 - 24.06.2016. Praha: GRADA PUBLISHING. 2016, pp. 1468-1475. 1st edition, Prague, June 2016, Complete edition printed version + Flash disk with full paper version. ISBN 978-80-271-0248-8.

[8] UNIKA. Sazebník pro tvorbu nabídkových cen projektových prací a inženýrských činností

[9] Lévy, François. BIM in small-scale sustainable design. Hoboken: Wiley, (C2012.

[10] Zheng, HK., Cao, JW. (2013). Discussing the Influence of BIM for the Construction Project Cost. Ework and eBusiness in architecture, engineering and construction, pts 1-4, 357-360, 2533-2536.

[11] Arlati, E., Roberti, L., Tarantino, S. (2009). BIM Towards design documentation: Experimental application work-flow to match national and proprietary standards. Architecture, Building materials and engineering management, 495-505. https://doi.org/10.1201/9780203883327.ch55.

[12] Volk, R., Stengel, J., Schultmann, F. (2014). Building Information Modeling (BIM) for existing buildings literature review and future needs, Automation in Construction, 38, 109-127. https://doi.org/10.1016/j.autcon.2014.02.010.

[13] MATĚJKA, P., et al. The Integration of BIM in Later Project Life Cycle Phases in Unprepared Environment from FM Perspective [online]. In: Procedia Engineering. Creative Construction Conference 2016.

Budapest, 25.06.2016 - 28.06.2016. Amsterdam: Elsevier B.V.. 2016, pp. 550-557. vol. 164. ISSN 18777058. Available from: http://www.sciencedirect.com/science/article/pii/S1877705816339984 https://doi.org/10.1016/j.proeng.2016.11.657. 
[14] SCHNEIDEROVÁ, R. The Building's Value Assesment using the Utility and the LCC. In: Central Europe towards Suistainable Bulding 07 Prague. Central Europe towards Suistainable Bulding 07 Prague. Praha, 24.09.2007 - 26.09.2007. Praha: České vysoké učení technické v Praze, Fakulta stavební. 2007, pp. 126131. ISBN 978-80-903807-8-3.

[15] SCHNEIDEROVÁ HERALOVÁ, R. Life Cycle Cost Analysis in Public Procurement. In: HÁJEK, P., et al., eds. Central Europe towards Sustainable Building 2013. Central Europe towards Sustainable Building 2013. Praha, 26.06.2013 - 28.06.2013. Praha: Grada. 2013, pp. 781-784. ISBN 978-80-247-5018-7

[16] KALINICHUK, S. and TOMEK, R. Agile PM and BIM: A Hybrid Scheduling Approach for a Technological Construction Project. Procedia Engineering. 2015, 123pp. 557-564. ISSN 1877-7058. Available from: http://www.sciencedirect.com/science/article/pii/S1877705815032099 https://doi.org/10.1016/j.proeng.2015.10.108.

[17] MATĚJKA, P., et al. The Implementation of Building Information Modeling into Educational Programs at CTU in Prague. In: LUPÍŠEK, A., et al., eds. Central Europe towards Sustainable Building 2016 Innovations for Sustainable Future. Central Europe towards Sustainable Building 2016 Innovations for Sustainable Future. Prague, 22.06.2016 - 24.06.2016. Praha: GRADA PUBLISHING. 2016, pp. 853-860. 1st edition, Prague, June 2016, Complete edition - printed version + Flash disk with full paper version. ISBN 978-80-271-0248-8. 